Анамариа Бене

Универзитет у Новом Саду

Учитељски факултет

на мађарском наставном језику
811.511.14'367.622.22

https://doi.org/10.18485/climb.2017.5.2.ch6

\title{
ОДНОС МАЂАРСКЕ ЛИНГВИСТИКЕ И ПРИРОДНИХ НАУКА
}

\section{Сажетак}

Године 1869-е оснивач мађарске класичне филологије Емил Понори Терек (Ponori Thewrewk Emil) издаје у Пешти кратку монографију коју насловљава „A nyelvészet mint természettudomány” (P. Thewrewk 1869) у преводу: „Лингвистика као природна наука". ${ }^{1}$ Она врло брзо пада у заборав, али после више од века тврдња наслова постаје извор до данас постојећег великог, али и продуктивног конфликта у мађарској лингвистици, из којег су израсла не само капитална научна дела, већ и неколико светски признатих лингвиста - представника савременог структурализма.

Кључне речи: мађарски, трансформационо-генеративна лингвистика (структурализам), традиционална лингвистика, друштвена наука, природна наука

Од средине 60-их година прошлог века у Мађарској се развија тада нова грана лингвистике: математичка и рачунарска лингвистика (данас позната као језичка технологија). Њени пионири били су истраживачи који су формално образовање стекли не само из филолошких наука, већ и из математике: неколико њих² добија Фордову стипендију и могућност истрживања на америчким универзитетима, где се упознају са у то време новом трансформационо-генеративном

1 Преводи у тексту су ауторови.

2 Ференц Кифер (Kiefer Ferenc, Апатин, 1931-), Ђерђ Cene (Szépe György, 1931-2012), Ласло Антал (Antal László, 1930-1993), Иван Фонађ (Fónagy Iván, 1920-2005), Жигмонд Телегди (Telegdi Zsigmond, 1909-1994) 
лингвистиком, коју ће по повратку предавати на будимпештанском универзитету „Лоранд Етвеш“.

Појава савременог структурализма или трансформационогенеративне граматике и лингвистичких радова Ноама Чомског у Мађарској покретач је огромног развоја ове науке, али уједно и узрочник раскола међу лингвистима, који је временом израстао у непремостиви понор.

Најрадикалнији став у генеративном табору јесте да се као последица ширења Јакобсонових и Сосирових учења, те радова Блумфилда и Зелига Хариса до другог дела прошлог века одиграо лингвистички преокрет („linguistic turn”), због чега се променио предмет и методика истраживања, али и начин описа језичких појава, те лингвистика не припада више друштвеним, него природним наукама. Једна од „последица“ овог става и оваквог приступа језичким истраживањима, што се тиче мађарске лингвисике је то да је мађарски један од ретких језика на свету који је у целости описан у оквиру структуралне граматике, а друга са којом се бави и овај рад јесте двадесетогодишња дискусија „модерних“ и „старомодних“ лингвиста: генеративаца и дескриптиваца.

Питање око којег се води најжустрија полемика међу мађарским лингвистима је питање да ли науку о језику посматрајући њен развој у историјском континууму данас треба сматрати друштвеном или природном науком. Тачније, постоји ли лингвистичка теорија која на основу метода и алата које користи у описивању једног језика треба бити категорисана као природна наука? При томе, сами традиционални (дескриптивни) лингвисти, значи противници ове идеје прихватају као чињеницу то да је адекватан опис језика могућ једино уз помоћ алата и метода природних наука, али сматрају да лингвистика, па тако и трансформационо-генеративна никада није била у стању постати природном науком: она је дан данас друштвена наука.

Распрострањено је мишљење, те опште прихваћено и у генеративистичким круговима у Мађарској да је прегенеративна или традиционална (дескриптивна) лингвистика недвосмислено друштвена наука, а разлоге за то треба тражити у њеном начину дефинисања предмета свог истраживања и вршења истраживања.

Традиционална (дескриптивна) лингвистика изучава језик као апстрактну друштвену тековину. Мађарска традиционална (дескрип- 
Култура и/или наука

тивна) лингвистика изучава мађарски језик као апстракцију која се манифестује у писаним и говорним текстовима: у књижевним делима писаним на мађарском и у исказима говорника мађарског као матерњег језика. Пошто изучава и описује језик као друштвену тековину, а анализира је индуктивном и дескриптивном методом, себе сматра друштвеном науком.

С друге стране, трансформационо-генеративна лингвистика има за циљ опис језичке компетенције (спремности) појединца. Наиме, заснована на Сосировом „преструктурализму“ (Szépe 1960: 144) разликује компетенцију (и то компетенцију говорника датог језика као матерњег) и перформансу (Saussure 1997), то јест језичку делатност: конкретну манифестацију матерњег језика. Чак је и предмет њеног истраживања компетенција на матерњем језику, али наспрам традиционалне (дескриптивне) лингвистике трансформационо-генеративна лингвистика сматра да је језик биолошки ентитет, а не друштвена тековина.

Трансформационо-генеративну лингвистику интересује шта је то што говорнику нпр. мађарског као матерњег језика омогућава да на свом матерњем језику разуме и изведе неограничен број реченица; одреди која је од изведних реченица могућа, граматички правилна, а која није. Другим речима, трансформационо-генеративна лингвистика настоји да опише/моделује менталну граматику појединца. По њеном схватању опис једног језика је адекватан једино онда, ако је експлицитан, а дефинисана правила могу се формализовати и алгоритмовати. Добра је она граматика, која омогућава извођење свих могућих граматички правилних реченица, и искључује извођење граматички неправилних структура. Из ових разлога она изучава граматику појединца дедуктивном методом карактеристичном за природне науке. Услов за дедуктивну анализу једног језика је хипотеза по којој је језик генетички одређен биолошки ентитет, затворени систем којим управљају строго дефинисана правила од којих нема изузетака.

Значи, трансформационо-генеративна лингвистика изучава компетенцију (спремност) појединца - говорника матерњег језика, јер претпоставља да је компетенција (спремност) по Чомском: скуп знања о језику које сваки појединац подсвесно поседује (Chomsky 1965: 3-4). Овај скуп знања о језику је биолошки ентитет: специфич- 
но функционисање одређених можданих структура. Уколико је тачно да знање (когницију), њену суштину и употребу изучавају когнитивне науке, онда је и трансформационо-генеративна лингвистика когнитивна наука, а пошто когнитивне неуке спадају у домен природних наука, онда је и трансформационо-генеративна лингвистика природна наука. ${ }^{3}$ Овај преокрет трансформационо-генеративна лингвистика назива когнитивном револуцијом. Управо је публикација коју се објавила пре двадесетак година светски призната лингвисткиња, академкиња Каталин Е. Киш (É. Kiss 1998), а која разматра става да трансформационо-генеративна лингвистика изучава биолошки детерминовану конкретност, и због тога је природна наука иницирао велику дискусију у мађарским лингвистичким круговима.

Неспорно је да се мађарска традиционална (дескриптивна) лингвистика бави дескрипцијом језичких појава и прописивањем система језичких правила (прескрипцијом), док трансформационо-генеративна лингвистика има за циљ објашњење истих тих језичких појава, те се не задовољава пуким описом, већ жели продрети у суштину самог језика. Али у овој дискусији поставља се питање: да ли је то довољан разлог да буде окарактерисана као природна наука? Да ли је трансформационо-генеративна лингвистика способна да помоћу алата и метода природних наука анализира и формализира језик као биолошки детерминовану конкретност (Gecső 2002)?

Трансформационо-генеративна лингвистика је у праву када каже де једино језик као биолошки одређена конкретност може бити предмет лингвистичке (научне) анализе, али ако мало размислимо спознаћено да она, баш као и традиционална (дескриптивна) лингвситика изучава говор (parole), никако језик (langue), јер када, на пример, трансформационо-генеративна синтакса описује структуру произвољне реченице, она не описује говорникове мождане функције које се одвијају у тренутку генерисања те реченице (не описује низ когнитивних процеса), већ само њену унутрашњу структуру. Питања које су поводом ових теза постављају мађарски традиционални лингвисти су:

- Да ли је могуће из карактеристика говора (parole), шта више, говора појединца извести закључке о језику (langue)? А ако јесте, на који начин?

3 Сам Чомски пише да лингвистика спада у домен психологије, и самим тим је природна наука (Chomsky 1959). 
Култура и/или наука

- $\quad$ Да ли је Минималистички програм (Chomsky 1995) стварно адекватан опис тих можданих функција?

- Да ли су принципи и параметри (Chomsky 1982) стварно скуп правила која описују савладавање матерњег језика?

- И додајмо још једно питање из угла посматрача: да ли су сви ови системи примењиви и на билингвалне говорнике?

Стигли смо и до вероватно најпровокативније тврдње генеративне лингвистике, о којој се највише полемише у мађарским лингвистичким круговима, а то је натизам: урођено знање граматике. По Чомском принципи и параметри, то јест универзална граматика која по генеративној теорији управља учењем матерњег језика генетички је одређена (кодирана). Он препоставља да постоји језички ген (или гени) са кодираним универзалним принципима и параметрима (универзалном граматиком) која су основ учења матерњег језика.

Интересантно је да мађарски традиционални (дескриптивни) лингвисти када се ради о систему принципа и параметара не оспоравају постојање самих универзалних принципа, већ њихову генетичку одређеност. Јер, како они аргументовано тврде већа је вероватноћа да дете учећи матерњи језик на основу повратних језичких информација/језичких чињеница „докучи“ и само дефинише правила творбе разних структура, него да има у својој ДНК језички ген (или гене) са кодираном универзалном граматиком као основом савладавања матерњег језика. По ставу мађарских традиционалних (дескриптивних) лингвиста универзални принципи су у ствари универзални параметри: дететов матерњи језик је језик којим се служи његова непосредна околина, те слушајуђи је оно дефинише услове (правила) под којима је једна структура могућа, то јест граматички правилно формулисана. Значи, по њима пре ће бити да постоје универзални и језички специфични параметри. Међутим, универзални параметри нису генетски одређени, већ морају бити научени исто као и језички специфични параметри: учење матерњег језика одвија се постепено, хијерархијским редоследом почевши од најпростијих, јер су једноставне структуре основа за савладавање сложених. Ово је универзална особина свих језика, а не неки језички независтан језички принцип. Човек се не рађа са генетички кодираним принци- 
пима, већ учећи матерњи језик (али и све друге!) препознаје узајамне језичке везе, те формулише правила и принципе могућих, граматички правилно формулисаних структура.

Узмимо као пример структуралну и лексичку хомонимију у мађарском. Разумевање структуралне хомонимије (1-2) изискује врло добро познавање сложених синтактичких структура мађарског језика, јер се она појављује на нивоу синтаксе, а код примера (2) и владање номинализацијом, која је у мађарском у суштини морфосинтактички процес, и чије је усвајање могуће тек након савладавања свих морфолошких елемената, као и правила извођења морфолошких и синтактичких структура. Пример (3) је случај полисемије, а њено разумевање изискује поред усвојених комплексних синтактичких правила и врло развијен ментални лексикон, а заједно са њим разумевање и разликовање хомонимије и полисемије.

(1) [A szőke Éva és Anna] szépen szavalnak.

о.чл. плава Ева и Ана лепо рецитују

Плава Ева и Ана лепо рецитују.

1. значење: само о Еви тврдимо да је плава, и у том случају синтактичка структура би била оваква: [[A szőke Éva] és Anna] szépen szavalnak.

2. значење: и Ева и Ана су плаве, а структура изгледа овако: [A szőke [Éva és Anna]] szépen szavalnak.

$$
\begin{array}{lll}
\text { Péter ellenzi } & \text { [a misszionáriusok fözését]. } \\
\text { Петар противи се о.чл. мисионари } & \text { кување-акуз. }
\end{array}
$$

Петар се противи кувању мисионара.

1. значење у мађарском: 'Петар се противи кувању мисионара.'

У овом случају номинална фраза („a misszionáriusok fözése” 'кување мисионара') изведена је из реченице „A misszináriusokat-acc fözik pro-nom.pl.." ('Мисионаре кувају.').

2. значење реченице у мађарском је: 'Петар се противи кухињи мисионара.'

Овде би се номинална фраза („, a misszionáriusok fözése” 'кување мисионара') изводила из реченице „A misszionárisok-nom.pl. föznek.”( 'Мисионари кувају.').

(3) Péter szerzett egy könyvet a piacról.

Петар набавио нео.чл. књига-акуз. о.чл. пијаца-лок.

Петар је набавио једну књигу са пијаце.

Пошто је именица ріас полисем у мађарском: ріас ${ }^{1}$ 'пијаца', piac ${ }^{2}$ 'тржиште', могућа су следећа значења ове реченице: 


\section{Култура и/или наука}

1. 'Петар је набавио једну књигу са пијаце.'

2. 'Петар је набавио једну књигу о тржишту.'

Натизам је нешто у шта мађарски генеративни лингвисти дубоко верују. Али, теорија Чомског о урођеној универзалној граматици која је како је он формулисао: већ „умрежена“ у мозак, и током учења матерњег језика, а дете само треба да обави повезивање, често је дискутована тема у мађарским научним круговима, и то не само у лингвистичким. Мађарски неуролог, академик Силвестер Е. Визи написао је следеће: „...a klasszikus dogma, azaz hogy [...] az agy müködése csak úgy képzelhető el, mint egy huzalozott rendszer, valósznüleg nem igaz." (Vizi 2001: 1156) (,...класична догма, то јест [...] да се функционисање људског мозга може замислити једино као умрежени систем, вероватно није тачна.").

У последње време све су гласнији они који би да ублаже радикалне ставове великих имена мађарске генеративне граматике. По њима лингвистика, па тако и мађарска лингвистика због својих специфичности никада није била у стању прећи границу између друштвених и природних наука: она је и сада друштвена наука, јер и данас изучава говор (parole)! Али, с обзиром на то да је у савременој лингвистици адекватан опис језичких појава могућ само помоћу алата и метода природних наука (пре свега логике и математике) врло је могуће да ће се у не тако далекој будућности догодити „природно-научни лингвистички преокрет“, и то ће нам најзад омогућити описивање/моделирање језика (langue).

\section{Извори и литература}

Gecső Tamás. „A nyelvi leírás határmezsgyéjén: társadalomtudomány vagy természettudomány?" Magyar Nyelv, XCVIII.3 (2002): 300-305. Štampano.

Chomsky, Noam. The Minimalist Program. Cambridge, Mass: The MIT Press, 1995. Štampano.

Chomsky, Noam. Lectures on Government and Binding: The Pisa Lectures. Dordrecht, Holland-Cinnaminson, U.S.A.: Foris Publications, 1982. Štampano.

Chomsky, Noam. Aspects of the Theory of Syntax. Cambridge, Mass: The MIT Press, 1965. Štampano.

Chomsky, Noam. „Review of Skinner's Verbal Behavior.“ Language, 35 (1959): 26-58. Štampano. 
É. Kiss Katalin. „A generatív nyelvészet mint kognitiv tudomány." Pléh, Csaba-Győri, Miklós (szerk.). A kognitív szemlélet és a nyelv kutatása. Budapest: Pólya Kiadó, 1998. 23-39. Štampano.

Ponori Thewrewk Emil. A nyelvészet mint természettudomány, Pest: Khór és Wein, 1869. Štampano.

Sausssure, Ferdinand de. Bevezetés az általános nyelvészetbe. Budapest: Corvina, 1997. Štampano.

Szépe György. „Vita a Saussure-i tanítások magyar visszhangjáról.” Nyelvtudományi Közlemények, 62 (1960): 143-146. Štampano.

Vizi E. Szilveszter. „Az agy és a tudat kapcsolata, digitális és analóg ingerületátvivő rendszerek." Magyar Tudomány, 10 (2001): 1152-1162. Štampano.

Annamária Bene

University of Novi Sad

Teachers' Training Faculty in Hungarian

\section{HUNGARIAN LINGUISTICS}

\section{AND THE NATURAL SCIENCES}

\section{Summary}

Hungarian linguists dispute the issue whether linguistics belongs with the humanities or the natural sciences a fairly long time. The involved parties: generativists and descriptivists argue for and against linguistics, i.e. linguistic research being a natural science. The latter claim that ere now linguistics, including generative linguistics should be still assigned to the humanities, since it studies the Saussurean parole, despite all the self claims to the contrary. However, since a language description is adequate only if it applies tools and methods of the natural sciences, it is very likely that the future of linguistics lies in the natural sciences. For this to come true, another linguistic turn would be needed, whereby linguists would be able by using tools and methods of the natural sciences to study and to model the Saussurean langue. 